\title{
FACTORS INFLUENCING RESILIENCE OF PRIMARY SCHOOL TEACHERS, HULU LANGAT, SELANGOR
}

\author{
Tho Mei Hui ${ }^{\text {a* }}$, Dr Zuraidah Abdullah ${ }^{\text {b }}$ \\ ab* Education Management, Planning and Policy, Faculty of Education \\ University of Malaysia \\ Kuala Lumpur, Malaysia, ${ }^{a^{*}}$ thomeihui@ymail.com ${ }^{\text {b) }}$ zuraidahab@um.edu.my
}

\begin{abstract}
This study aimed to explore the factors influencing resilience of primary school teachers, Hulu Langat, Selangor. The research design used in this study is quantitative, and survey question is used to collect the data. A total of 351 respondents is randomly selected. Research findings are analysed using statistical descriptive and inferences. Findings show that the level of teachers' resilience $(\mathrm{M}=3.92, \mathrm{SD}=.44)$ are high. The mean score of each dimension is personal competence $(\mathrm{M}=3.77, \mathrm{SD}=.57)$, social competency $(\mathrm{M}=3.99, \mathrm{SD}=.55)$, social resource $(\mathrm{M}=3.85, \mathrm{SD}=.54)$, family cohesion $(\mathrm{M}=4.20, \mathrm{SD}=.65)$. and structure style $(\mathrm{M}=3.77, \mathrm{SD}=.48)$. This study helps teachers to improve their resiliency, enables them to remain in the teaching profession and commits to the job which was assigned to them.
\end{abstract}

Keywords: teachers resilience, teaching profession,

\section{INTRODUCTION}

In 21 century, many researchers talking about resiliency. Resilience had been viewed as the ability and quality of individual manage stress, problems and challenge. Moreover, resilience also viewed as ability "bouncing back" for adversity and setbacks (Beltman et al., 2011). Teacher resilience becomes a main key to outstanding teaching and learning process.

Teachers who are resilience tend to respond positively in the stressful classroom or school environment and derive deeper satisfaction in their work (Gu \& Day, 2007). Such behaviours and responds help neither senior teachers nor beginning teachers has the ability and power to stay in the teaching profession. Furthermore, satisfaction in work also leads job commitment among teacher.

Since last two decades, resilience has become a hot topic and have been widely studying by the educational researchers around the world due to the significant implication on teacher work attitude such as commitment, retention, work satisfaction and performance (Gu, 2014; A. Z. A. Razak, 2013; Tait, 2008). Retaining teachers in the teaching profession is a major concern in many countries (J. Y. Hong, 2012). Teacher's resilience enable teachers persist in the face for challenges and provide the ways to cope the stress, burnout and attrition.

In brief, promoting teacher resilience is become an emergedissues in the education system. Resiliency for teachers enables them to remain in the teaching profession and show commitment to the job which was assigned to them.

\section{METHODS}

\section{Research Design}

Research methodology is used to solve the research problems (Kothari, 2004). It can be defined as various steps generated by researcher in studying research problems. 
Singleton and Straits (2010) described several steps of methodology used to identify, select and analyse information to understanding the problems study.

The research design used in this study is quantitative method. According to Creswell (2003), quantitative method is used to identify or investigate factors that influence an outcome. This study is mainly to find out the factors contributing teacher resilience and its collaboration with teacher commitment in school organisation.(Mansfield et al., 2012)
Moreover, this research design is chosen for because it allowed researcher conducting study in a large sample with limited resources. Quantitative method is applicable to phenomena that can be expressed in terms of quantity (Kothari, 2004). In this study, researcher interest in investigating the perception of teachers and this type of investigation can be expressed in quantities mode.

Table 3. 1 Summary of Method, Sample and Technique Used to Analyse Data

\begin{tabular}{llll}
\hline Research Method & Instrumentation & Sample respondents & Research analyses \\
\hline Quantitative & Survey Question & Teachers & $\begin{array}{l}\text { Descriptive statistics } \\
\text { Inferential statistics }\end{array}$ \\
\hline
\end{tabular}

\section{Population and Sampling}

The sampling used in this study is simple random sampling. This sampling also is known as "chance" and "probability" sampling (Kothari, 2004) whereby all the population has an equal chance and probability of being selected. Thus, in this study, all the primary school teacher's in Hulu Langat District are the target population and sample were selected randomly.

The population of primary school at Hulu Langat District is 4205 teachers. Based on Krejcie and Morgan (1970), Table for Determining Sample Size from a Given Population, the sample chosen is 351 teachers from primary school at Hulu Langat. Table 3.2 show the number of samples of the study randomly chose through two types of Malaysian primary school.

Table 3. 2Simple Random Sampling

\begin{tabular}{lr}
\hline Types of School & Samples \\
\hline National Primary School SK & 135 \\
Chinese Primary School SJKC) & 151 \\
Tamil Primary School SJK (T) & 65 \\
Total & 351 \\
\hline
\end{tabular}

\section{Likert Scale}

Likert Scale was firstly developed and introduced by Dr. Rensis Likert, a sociologist at the University of Michigan in 1932. This technique is commonly used by educational researcher as a scientific method to measure the psychological attitude of people (Bertram, 2007). In this study, five Likert scale scoring was developed. It used to measure the feedback attitude from the respondents. Table 3.3 shows the five Likert scale scoring.

Table 3. 3 Five Likert Scale

\begin{tabular}{ccccc}
\hline $\mathbf{1}$ & $\mathbf{2}$ & $\mathbf{3}$ & $\mathbf{4}$ & $\mathbf{5}$ \\
\hline Strong & Disagree & Quite & Agree & Strongly \\
$\begin{array}{c}\text { Disagree } \\
\text { (SD) }\end{array}$ & (D) & $\begin{array}{c}\text { Agree } \\
\text { (A) })\end{array}$ & $\begin{array}{l}\text { Agree } \\
\text { (SA) }\end{array}$ \\
\hline
\end{tabular}

\section{RESULTS AND DISCUSSION}

\section{A. Results}

This chapter explains in detail the research results gained from the study. The data was collected from three hundred and fifty-one respondents who are primary school teachers. The respondents answered the questionnaire that consisted two sections includes demographic information of respondents, teacher resilience. The data will be analysed using SPSS version 21. Descriptive statistical are employed to analyse the data obtained from school teachers.

\section{Demographic Information of Respondents}


In this section, the research results related to the demographic information of respondents will be discussed in detail. The general demographic information includes gender, race, school background, highest qualification and teaching experience. The data gather from demographic information is used to have a better understanding about the respondents. The following tables are the detailed analysis of respondents' demographic information.

\section{Gender Distribution}

Table 4.1 shows that there are 93 (26.5\%) male respondents who participate in this study and for female respondents, the frequency rate is 258 which accounted for $73.5 \%$. Female respondents are three times more than male respondents.

Table 4. 1 Demographic Information of Respondents - Gender

\begin{tabular}{ccc}
\hline Gender & Frequency $(\mathbf{N})$ & Percentage $(\boldsymbol{\%})$ \\
\hline Male & 93 & 26.5 \\
Female & 258 & 73.5 \\
Total & 351 & 100.0 \\
\hline
\end{tabular}

\section{Race Distribution}

Table 4.2 shows the race distribution of respondents. In this study, the data shows that there are $135(38,5 \%)$ Malay respondents and $145(41.3 \%)$ Chinese respondents. A total of 71 respondents is Indian which accounted for only $20.2 \%$ of the total respondents.

Table 4. 2 Demographic Information of Respondents - Race

\begin{tabular}{lll}
\hline Race & Frequency $(\mathbf{N})$ & Percentage $\mathbf{( \% )}$ \\
\hline Malay & 135 & 38.5 \\
Chinese & 145 & 41.3 \\
Indian & 71 & 20.2 \\
Total & 351 & 100.0 \\
\hline
\end{tabular}

\section{Categories of School Distribution}

Table 4.3 below shown that 351 respondents from three difference categories of school included 135 (38.5\%) from SK, 151 (43.0\%) from SJK (C) and $65(18.5 \%)$ from SJK (T).

Table 4. 3 Demographic Information of Respondents - Categories of School

\begin{tabular}{lll}
\hline $\begin{array}{l}\text { Categories } \\
\text { of School }\end{array}$ & $\begin{array}{l}\text { Frequency } \\
(\mathbf{N})\end{array}$ & $\begin{array}{l}\text { Percentage } \\
(\%)\end{array}$ \\
\hline SK & 135 & 38.5 \\
SJK (C) & 151 & 43.0 \\
SJK (T) & 65 & 18.5 \\
Total & 351 & 100.0 \\
\hline
\end{tabular}

\section{Location of School Distribution}

Next, table 4.4 shows the location of school which respondents are currently working for. There are a total of $283(80.6 \%)$ respondents from urban schools. Whereas, only 68 respondents from rural schools which accounted for $19.4 \%$ of the total respondents.

Table 4. 4 Demographic Information of Respondents - Location of School

\begin{tabular}{lll}
\hline $\begin{array}{l}\text { Location } \\
\text { of School }\end{array}$ & $\begin{array}{l}\text { Frequency } \\
(\mathbf{N})\end{array}$ & $\begin{array}{l}\text { Percentage } \\
(\%)\end{array}$ \\
\hline Urban & 283 & 80.6 \\
Rural & 68 & 19.4 \\
Total & 351 & 100.0 \\
\hline
\end{tabular}

\section{Highest Qualification Distribution}

In addition, table 4.5 shows the highest qualification of respondents. Most of the respondents had Bachelor level with the frequency rate $262(74.6 \%)$. Next, there are 49 $(14.0 \%)$ of respondents had a diploma level 38 $(10.8 \%)$ had a master level. Only $2(0.6 \&)$ respondents had SPM or STPM level. None of the respondents had Doctorate $(\mathrm{PhD})$ level.

Table 4. 5 Demographic Information of Respondents - Highest Qualification

\begin{tabular}{lll}
\hline $\begin{array}{l}\text { Highest } \\
\text { Qualification }\end{array}$ & $\begin{array}{l}\text { Frequency } \\
(\mathbf{N})\end{array}$ & $\begin{array}{l}\text { Percentage } \\
(\%)\end{array}$ \\
\hline SPM/STPM & 2 & 0.6 \\
Diploma & 49 & 14.0 \\
Bachelor & 262 & 74,6 \\
Master & 38 & 10.8 \\
Doctorate $(\mathrm{PhD})$ & 0 & 0 \\
Total & 351 & 100,0 \\
\hline
\end{tabular}

\section{Teaching Experience Distribution}

As Table 4.6, the analysis shows that the majority of the respondents have teaching experience between 6-10 years, which the frequency rate is $110(31.3 \%)$. Next, $28(8 \%)$ respondents are teaching less than 1 year, 84 $(23.9 \%)$ teaching between $1-5$ years, 96 (27.4\%) teaching between11-15 years and 20 
(5.7\%) teaching between 16-20 years. The fewest number of respondents teaching 20 years and above, which the frequency rate is only $13(3.7 \%)$.

Table 4. 6 Demographic Information of Respondents - Teaching Experience

\begin{tabular}{lll}
\hline $\begin{array}{l}\text { Teaching } \\
\text { Experience }\end{array}$ & $\begin{array}{l}\text { Frequency } \\
(\mathbf{N})\end{array}$ & $\begin{array}{l}\text { Percentage } \\
(\boldsymbol{\%})\end{array}$ \\
\hline Less than 1 year & 28 & 8.0 \\
1-5 years & 84 & 23.9 \\
6-10 years & 110 & 31.3 \\
11-15 years & 96 & 27.4 \\
16-20 years & 20 & 5.7 \\
20 years and above & 13 & 3.7 \\
Total & 351 & 100.0 \\
\hline
\end{tabular}

Factors Influencing Teacher Resilience

In this section, descriptive statistical is used to investigate teacher self-perception on the factors that enable them to be resilient in school organization. Teacher resilience scale is divided into five different aspects which are Personal Competence, Social Competence, Social Resource, Family Cohesion and Structure Style.

Table 4.7 shows the level determination of mean score. There is three difference level of score mean includes low level (.00-2.33), moderate level (2.34-3.66) and high level (3.67-5.00).

Table 4. 7 Level Determination of Mean Score

\begin{aligned} \hline Mean Score & Measurement Level \\ \hline $.00-2.33 &$ Low \\ $2.34-3.66 &$ Moderate \\ $3.67-5.00 &$ High \end{aligned}

Source: Muhammad Faizal A. Ghani and Gary M. Crow (2013)

In addition, Table 4.8 indicates the mean score for the proactive factors that enable teacher to be resilient is 3.92. The mean score is considered as high mean. This finding shows that resiliency for primary school teachers' are well promoted in schools.

Table 4. 1 Factors Influencing Teacher Resilience

\begin{tabular}{lllll}
\hline Variable & $\begin{array}{l}\text { Mean } \\
\text { (M) }\end{array}$ & $\begin{array}{l}\text { Std. } \\
\text { (SD) }\end{array}$ & Deviation & Level \\
\hline $\begin{array}{l}\text { Teacher } \\
\text { Resilience }\end{array}$ & 3.92 & .44 & High \\
Factors & & & & \\
\hline
\end{tabular}

Factors Influencing Teachers' Resilience (Measures the Highest Mean)

In this section, Table 4.9 shows the mean score for all the proactive factors that help teachers' to be resilience. In this study, the results of finding indicate that family cohesion mean score is the highest mean among the five items of teachers' resilience factors, which accounted for 4.20. Primary school teachers in Hulu Langat perceived that family cohesion is the most important factors for them to be resilience. In contrast, personal competency and structure style show the least mean score, which is 3.77 .

Table 4. 9 Mean Score for All the Factors that Help Teachers' to be Resilience

\begin{tabular}{|c|c|c|c|}
\hline $\begin{array}{l}\text { Teachers' Resilience } \\
\text { Factors }\end{array}$ & $\begin{array}{l}\text { Mean } \\
(\mathrm{M})\end{array}$ & $\begin{array}{l}\text { Std. } \\
\text { Deviation } \\
\text { (SD) }\end{array}$ & Level \\
\hline a) Personal Competence & 3.77 & .57 & High \\
\hline b) Social Competence & 3.99 & .55 & High \\
\hline c) Social Resouce & 3.85 & .54 & High \\
\hline d) Family Cohesion & 4.20 & .65 & High* \\
\hline e) Structure Style & 3.77 & .48 & High \\
\hline
\end{tabular}

High* $=$ highest mean score

In next section, each proactive factors influencing teachers' resilience will be discussed in detail. The mean score and standard deviation are used to measure the level of teacher's resilience.

\section{Personal Competence}

In this study, personal competence is one of the personal protective factors contributing teachers' resilience. According to the Table 4.10, the mean score of each item is as follows: TRA1 $(\mathrm{M}=3.80, \mathrm{SD}=.88)$, TRA2 $(\mathrm{M}=3.72$, $\mathrm{SD}=.78)$, TRA3 $(\mathrm{M}=3.81, \mathrm{SD}=.79)$, TRA4 $(\mathrm{M}=3.89, \mathrm{SD}=.61)$ and TRA5 $(\mathrm{M}=3.73$. SD $=.86)$. The findings show that item TRA4 obtained highest mean score, which teachers in primary school perceived themselves as having 
a high level of problem-solving skills. In general, all the items of personal competency are at high level.

In other words, teachers agreed that they have the personal competence skills such as belief in the ability to make a difference in workplace and success in the teaching profession. Moreover, teachers also have the capacity to face the challenges which occur in their teaching life. In sum, the overall mean score for items of personal competence is high $\mathrm{M}=3.79$.

Table 4. 10 Factors Influencing Teachers' Resilience - Personal Competence

\begin{tabular}{|c|c|c|c|c|c|c|c|c|c|}
\hline \multirow{2}{*}{$\begin{array}{c}\text { Item } \\
\text { No }\end{array}$} & \multirow[t]{2}{*}{ Statement } & \multicolumn{5}{|c|}{5 Point Likert Scale Scoring } & \multirow[t]{2}{*}{$\mathbf{M}$} & \multirow[t]{2}{*}{ SD } & \multirow{2}{*}{$\begin{array}{l}\text { Level } \\
\text { High }\end{array}$} \\
\hline & & SD & $\mathrm{D}$ & QA & $\mathrm{A}$ & SA & & & \\
\hline TRA1 & $\begin{array}{l}\text { I believe in my ability } \\
\text { to make a different in } \\
\text { my career. }\end{array}$ & 1.4 & 6.8 & 20.8 & 53.6 & 17.4 & 3.80 & .88 & \\
\hline TRA2 & $\begin{array}{l}\text { I can face the } \\
\text { challenges which } \\
\text { occur in my teaching } \\
\text { life. }\end{array}$ & .6 & 9.1 & 18.5 & 61.8 & 10.0 & 3.72 & .78 & High \\
\hline TRA3 & $\begin{array}{l}\text { I believe in myself } \\
\text { that I will success in } \\
\text { teaching profession. }\end{array}$ & .6 & 5.4 & 22.8 & 54.7 & 16.5 & 3.81 & .79 & High \\
\hline TRA4 & $\begin{array}{l}\text { When I am } \\
\text { confronted with a } \\
\text { problem, I can usually } \\
\text { find several solutions. }\end{array}$ & .0 & 1.4 & 20.2 & 65.5 & 12.8 & 3.89 & .61 & High* \\
\hline TRA5 & $\begin{array}{l}\text { I am confident that I } \\
\text { could deal efficiently } \\
\text { with unexpected } \\
\text { events in school. }\end{array}$ & .0 & 11.1 & 21.4 & 51.0 & 16.5 & 3.73 & .86 & High \\
\hline & Dverall Mean Score & & & & & & & 3.79 & .78 \\
\hline
\end{tabular}

$\mathrm{SD}=$ Strongly Disagree, $\mathrm{D}=$ Disagree, $\mathrm{QA}=$ Quite Agree, $\mathrm{A}=$ Agree, $\mathrm{SA}=$ Strongly Agree

High $^{*}=$ highest mean score

\section{Social Competence}

Besides, Table 4.11 below shows the findings of personal social competence as the factor influencing teacher resilience. The mean score of each item is as follows: TRB1 ( $M=4.00$, $\mathrm{SD}=.69)$, $\mathrm{TRB} 2(\mathrm{M}=4.06, \mathrm{SD}=.79), \mathrm{TRB} 3$ $(\mathrm{M}=4.10, \mathrm{SD}=.66)$, and TRB4 $(\mathrm{M}=3.91, \mathrm{SD}$ $=.73)$. The result of the findings shows that item TRB3 obtained highest mean score as teachers strongly agree that they can communicate well with their colleagues, peers and students in school. In addition, the findings also show that mean score for all the items of social competence is at high level.

As conclusion, teachers in Hulu Langat perceived themselves as having high level of social competence. They enjoy being together with the colleagues and always have an open ear when other teachers came to them. They also build a good relationship with the members in school. Overall mean score for items of social competence is high $\mathrm{M}=.4 .02$ 
Table 4. 2 Factors Influencing Teacher Resilience - Social Competence

\begin{tabular}{|c|c|c|c|c|c|c|c|c|c|}
\hline \multirow{2}{*}{$\begin{array}{c}\text { Item } \\
\text { No }\end{array}$} & \multirow[t]{2}{*}{ Statement } & \multicolumn{5}{|c|}{5 Point Likert Scale Scoring } & \multirow[t]{2}{*}{$\mathbf{M}$} & \multirow[t]{2}{*}{ SD } & \multirow[t]{2}{*}{ Level } \\
\hline & & SD & $\mathrm{D}$ & QA & A & SA & & & \\
\hline TRB1 & $\begin{array}{l}\text { I always have an open } \\
\text { ear when other } \\
\text { teachers came to me } \\
\text { with their problems. }\end{array}$ & .0 & 2.8 & 15.4 & 60.4 & 21.4 & 4.00 & .69 & High \\
\hline TRB2 & $\begin{array}{l}\text { I enjoy being together } \\
\text { with my colleagues at } \\
\text { school/ work. }\end{array}$ & .0 & 3.4 & 18.5 & 47.3 & 30.8 & 4.06 & .79 & High \\
\hline TRB3 & $\begin{array}{l}\text { I can communicate } \\
\text { well with my } \\
\text { a) colleagues } \\
\text { b) peers } \\
\text { c) Students }\end{array}$ & .0 & .6 & 15.4 & $\mathbf{5 7 . 5}$ & 26.5 & 4.10 & .66 & High* \\
\hline TRB4 & $\begin{array}{l}\text { It's easy for me to } \\
\text { establish a friendly } \\
\text { relationship at school. }\end{array}$ & .3 & .6 & 28.8 & 48.7 & 21.7 & 3.91 & .73 & High \\
\hline & Dverall Mean Score & & & & & & & 4.02 & 72 \\
\hline
\end{tabular}

$\mathrm{SD}=$ Strongly Disagree, $\mathrm{D}=$ Disagree, $\mathrm{QA}=$ Quite Agree, $\mathrm{A}=$ Agree, $\mathrm{SA}=$ Strongly Agree

High $^{*}=$ highest mean score

\section{Social Resource}

In this study, social resource such as relationship and support form leaders, colleagues, peers and students are examined. Table 4.12 shows the mean score of the five items TRC1 $(\mathrm{M}=4.00, \mathrm{SD}=.68), \mathrm{TRC} 2(\mathrm{M}=$ 3.92, $\mathrm{SD}=.71), \mathrm{TRC} 3(\mathrm{M}=3.73, \mathrm{SD}=.82)$, TRC4 $(\mathrm{M}=3.77, \mathrm{SD}=.74)$ and TRC5 $(\mathrm{M}=$ $3.81, \mathrm{SD}=.77)$. Generally, all the items of social resource factors have high mean score.
Research findings show that item TRC1 obtained highest mean score as teachers agreed that there is somebody that always cares and supports them in school. Apart from this, the result indicates that teachers have the good relationship with their school leaders, colleagues and students. Meanwhile, colleagues and peers are willing to share their knowledge and experience in teaching. School headmaster also gives teachers support, praises and rewards. In sum, an overall mean score of social resource is high $\mathrm{M}=.3 .85$.

Table 4. 3 Factors Influencing Teachers' Resilience - Social Resource

\begin{tabular}{clllllllllllll}
\hline Item \\
No
\end{tabular}


support, praises and

rewards.

\begin{tabular}{|c|c|c|c|c|c|c|c|c|c|}
\hline TRC4 & $\begin{array}{l}\text { In school, there is } \\
\text { someone } \\
\text { appreciates } \\
\text { abilities. }\end{array}$ & .3 & 3.1 & 30.8 & 51.3 & 4.5 & 3.77 & .74 & High \\
\hline TRC5 & $\begin{array}{l}\text { My colleagues and } \\
\text { peers are willing to } \\
\text { share their knowledge } \\
\text { and experience in } \\
\text { teaching. }\end{array}$ & .9 & 2.3 & 29.3 & 50.1 & 17.4 & 3.81 & .77 & High \\
\hline & Dverall Mean Score & & & & & & & 3.85 & 74 \\
\hline
\end{tabular}

$\mathrm{SD}=$ Strongly Disagree, $\mathrm{D}=$ Disagree, $\mathrm{QA}=\mathrm{Quite}$ Agree, $\mathrm{A}=$ Agree, $\mathrm{SA}=$ Strongly Agree

High $^{*}=$ highest mean score

The findings indicate that item TRD4

\section{Family Cohesion}

In addition, family cohesion refers as one of the contextual proactive factors promoting teachers' resilience. Table 4.13 indicates the mean score for each item TRD1 $(\mathrm{M}=4.15$, $\mathrm{SD}=.78)$, TRD2 $(\mathrm{M}=4.19, \mathrm{SD}=.79)$, TRD3 $(\mathrm{M}=4.23, \mathrm{SD}=.69)$ and $\mathrm{TRD} 4(\mathrm{M}=4.24, \mathrm{D}$ $=.75$ ). Additionally, the findings also show that all the items for family cohesion are at the high level. obtained a highest mean score, which is respondents agreed that in their family there is someone listen to them when they have something to say. Next, respondents perceived that their family members always giving love and support to them. They feel very happy with their family. Moreover, respondents also agreed that family members always believe that they can success in career are the factors for teachers to be resilience. In conclusion, overall mean score of family cohesion is high $\mathrm{M}=$ 4.20 .

Table 4. 4 Factors Influencing Teachers' Resilience - Family Cohesion

\begin{tabular}{|c|c|c|c|c|c|c|c|c|c|}
\hline \multirow{2}{*}{$\begin{array}{c}\text { Item } \\
\text { No }\end{array}$} & \multirow[t]{2}{*}{ Statement } & \multicolumn{5}{|c|}{5 Point Likert Scale Scoring } & \multirow[t]{2}{*}{$\mathbf{M}$} & \multirow[t]{2}{*}{ SD } & \multirow[t]{2}{*}{ Level } \\
\hline & & SD & $\mathrm{D}$ & QA & A & SA & & & \\
\hline TRD1 & $\begin{array}{l}\text { I feel very happy with } \\
\text { my family. }\end{array}$ & .0 & 2.0 & 18.2 & 43.0 & 36.8 & 4.15 & .78 & High \\
\hline TRD2 & $\begin{array}{l}\text { The members of my } \\
\text { family make an effort } \\
\text { to show their love and } \\
\text { support to me. }\end{array}$ & .0 & 2.8 & 15.7 & 41.3 & 40.2 & 4.19 & .79 & High \\
\hline TRD3 & $\begin{array}{l}\text { My family members } \\
\text { believe that I will be } \\
\text { success in my career. }\end{array}$ & .0 & 6 & 13.4 & 48.7 & 37.3 & 4.23 & .69 & High \\
\hline TRD4 & $\begin{array}{l}\text { In my family, there is } \\
\text { someone listen to me } \\
\text { when I have } \\
\text { something to say. }\end{array}$ & .0 & .9 & 16.5 & 40.5 & 42.2 & 4.24 & .75 & High* \\
\hline & Dverall Mean Score & & & & & & & 4.20 & 75 \\
\hline
\end{tabular}

$\mathrm{SD}=$ Strongly Disagree, $\mathrm{D}=$ Disagree, $\mathrm{QA}=$ Quite Agree, $\mathrm{A}=$ Agree, $\mathrm{SA}=$ Strongly Agree

High* $=$ highest mean score 


\section{Structure Style}

Furthermore, the findings of structure style factor are show in Table 4.14. The mean score of each item is as follows: TRE1 $(\mathrm{M}=4.01, \mathrm{SD}$ $=.71)$, TRE2 $(\mathrm{M}=3.77, \mathrm{SD}=.64), \mathrm{TRE} 3(\mathrm{M}=$ $3.68, \mathrm{SD}=.67)$ and TRE4 $(\mathrm{M}=3.79, \mathrm{SD}=$ $.62)$. Obviously, the findings indicate that all the items of structure style have high mean score.

In this study, the findings show that item TRE1 obtained highest mean among the five items of structure style. The respondents agreed that they will do their best to attain their goal. Furthermore, respondents also set a realistic goal, planning and executing successful lessons in schools and they prefer to have a thorough plan when started on new things or task assigned by the school leaders. Next, respondents perceived that they can organise and manage their time well in the classroom. As conclusion, an overall mean score of items for structure style is high $\mathrm{M}=4.20$.

Table 4. 5 Factors Influencing Teachers' Resilience - Structure Style

\begin{tabular}{|c|c|c|c|c|c|c|c|c|c|}
\hline \multirow{2}{*}{$\begin{array}{c}\text { Item } \\
\text { No }\end{array}$} & \multirow{2}{*}{ Statement } & \multicolumn{5}{|c|}{5 Point Likert Scale Scoring } & \multirow[t]{2}{*}{$\mathbf{M}$} & \multirow[t]{2}{*}{ SD } & \multirow[t]{2}{*}{ Level } \\
\hline & & SD & $\mathrm{D}$ & QA & A & SA & & & \\
\hline TRE1 & $\begin{array}{l}\text { When I have a goal, I } \\
\text { do my best to attain } \\
\text { it. }\end{array}$ & .6 & 1.1 & 18.2 & 56.4 & 23.6 & 4.01 & .71 & High* \\
\hline TRE2 & $\begin{array}{l}\text { I prefer to have a } \\
\text { thorough plan when I } \\
\text { start on new things or } \\
\text { task assigned by the } \\
\text { school leader. }\end{array}$ & .0 & 3.1 & 24.5 & 64.1 & 8.3 & 3.77 & .64 & High \\
\hline TRE3 & $\begin{array}{l}\text { I am good at } \\
\text { organising and } \\
\text { managing my time in } \\
\text { the classroom. }\end{array}$ & .0 & 4.3 & 30.2 & 58.1 & 7.4 & 3.68 & .67 & High \\
\hline TRE4 & $\begin{array}{l}\text { I set a realistic goal, } \\
\text { planning and } \\
\text { executing successful } \\
\text { lessons. }\end{array}$ & .0 & .9 & 29.3 & 59.5 & 10.3 & 3.79 & .62 & High \\
\hline TRE5 & $\begin{array}{l}\text { My colleagues and } \\
\text { staff members in } \\
\text { school said I am a } \\
\text { structure person. }\end{array}$ & 1.1 & 7.7 & 35.6 & 5.9 & 9.7 & 3.56 & .79 & Moderate \\
\hline & Dverall Mean Score & & & & & & & 3.76 & .68 \\
\hline
\end{tabular}

$\mathrm{SD}=$ Strongly Disagree, $\mathrm{D}=$ Disagree, $\mathrm{QA}=$ Quite Agree, $\mathrm{A}=$ Agree, $\mathrm{SA}=$ Strongly Agree

High* = highest mean score

\section{B. Discussion}

Generally, this study purposely conducted to determine the factors influencing teacher resilience of primary school teachers in Hulu Langat, Selangor.

In the previous chapter, the data was analysed using descriptive statistics and the results of findings are discussed in detail. The findings of this study used to answer the research objectives and research questions.

\section{Factors Influencing Teachers' Resilience}

Research Questions : What are the factors influencing teacher resilience built in the teaching profession? 
In this study, the descriptive statistical analysis is used to find the score mean of teacher resilience. The findings show that average mean score of teacher resilience in primary school in Hulu Langat is high, which accounted 3.92. In this study, the findings explore the level of factors influencing teachers' resilience. The findings show that the highest mean score is family cohesion ( $\mathrm{M}=4.20, \mathrm{SD}=.47)$, followed by social competence $(\mathrm{M}=3.99, \mathrm{SD}=$ $.55)$, social resource $(\mathrm{M}=3.85, \mathrm{SD}=.54)$. While personal competence and structure style have the sam mean score, which accounted 3.77 .

The results of this study show that average level of factors influencing teacher resilience is high. The results show similarities with the study by Pavin Ivanec et al. (2014). As a result, teachers, in general, have an optimistic view of their own resilience since their rating on all the dimension of resilience are shifted to higher values.

In this study, the results revealed that family cohesion factor $(\mathrm{M}=3.86, \mathrm{SD}=.47)$ achieved the highest mean score compared to the others four dimensions of teacher resilience. Teachers perceived themselves have the high level of family cohesion factors. Teachers agreed that in their family, there is someone always show love, support and believe in them. These findings are supported by Noltemeyer and Bush (2013).

Next, these findings indicated social competence factor $(\mathrm{M}=3.99, \mathrm{SD}=.55)$ as the second highest mean score among the five factors of teacher resilience. In this study, the findings show that teacher perceived themselves enjoy being together with their colleagues at school or work; have the ability to communicate well with their colleagues, peer and students and easily establish a friendly relationship at school. The findings are supported by Mansfield et al. (2012), they related social competence as the strong communication skills and building relationship with others.
Besides, findings show that social resource factor $(\mathrm{M}=3.85, \mathrm{SD}=.54)$ is the third highest mean score. As the results, teachers agreed that they have a good relationship with their leader, colleagues and students. Meanwhile, colleagues and peers are willing to share their knowledge and experience in teaching. School headmaster also gives teacher support, praises and rewards. Greenfield (2015) stated that a strong and supportive leaders can promote teachers' resilience. Supportive leaders always ensure their teachers have the ability in coping stressor and challenges circumstances (Mansfield et al., 2012).

Furthermore, the fourth highest mean score is personal competence factors $(\mathrm{M}=3.77, \mathrm{SD}=$ .57). In this study, teachers believe that they have the ability to make a different in their career. Next, teacher perceived that they can usually find several solutions when they confronted with a problem. The results show similarities with the previous study by Howard and Johnson (2004) which highlighted that personal competence includes strong selfefficacy belief, strong problem-solving skills are the major protective factor building teacher resilience.

Last but not least, the finding also revealed that structure style $(\mathrm{M}=3.77, \mathrm{SD}=.48)$ have a high level of mean score. As a result, teachers generally agreed that when they have a goal, they will do their best to attain it. Moreover, teachers perceived that they are good in organising and managing their time in the classroom. The results are supported by Friborg et al. (2003), stated that teachers who have high structure style set a realistic goal, planning and executing successful lessons in their daily work.

\section{Recommendation for Future Study}

In this study, few recommendation for future study being suggested. The recommendations provide some general idea and serve as guidance for future educational researcher. The recommendations are shown below: 
a) Qualitative study could be carried out to analyse the factors to contribute teachers resilience. Qualitative study will provide an in-depth perspective on the factors influencing teacher resilience. An instrument such as interview and observation could provide the researcher with different results. Such a study would enable the researcher to gather information which may not have been reported in a questionnaire method.

b) This study only involved teachers from 10 selected primary public schools in Hulu Langat. Thus, this finding might not be generalised to another primary school in another district. Cross-validation of the findings in another district in Selangor is strongly recommended. Therefore, future studies could be conducted in the different districts such as Klang, Hulu Selangor and Gombak in order to gather the validity and reliability of the findings.

c) In this study, the adapted questionnaire is restricted to primary school teachers. Therefore, cross-validation of the findings in other education contexts is recommended. Similar questionnaire can be used to other sample types such as kindergarten teachers, secondary school teachers or even university lecturers.

d) In this study, an online questionnaire is used to replace traditional distribute questionnaire. Researcher found that distribute questionnaire through online is more efficient, less time constraint and save money. Thus, in future studies, this new method is highly recommended to all future researchers.

\section{CONCLUSION/RECOMENDATION}

In this study, researchers purposely explore the factors influencing resilience of primary school teachers. The results revealed that all the mean score of the five factors such as personal competency, social competency, social resource, family cohesion and structure style are at the high level of mean score.
Teachers resilience view as the "power and quality" enable teachers' stay in teaching profession, sustain motivation and job commitment $(\mathrm{Gu}, 2014)$. A teacher who is lacking in resiliency are unable to carry out their task well, and this will, in turn affect their commitments.

In other words, resiliency is a critical element for teachers to meet all the challenges and commit in the education profession. Teachers' commitment can be considered as one of the most important aspects towards the performance and quality in education organisation. Teacher with high level of commitment had an effective bond with the school.

In a nutshell, no education system can succeed without the resilience and commitment of its teachers. The protective factors of teachers' resilience are to be taken into serious consideration and more support and professional development are given to make teaching profession vibrant and sustain.

\section{REFERENCES}

Abdullah, Z., \& Ghani, M. F. A. (2014). Professional Learning Community in Secondary Schools Community in Malaysia. Journal of Education and Learning (EduLearn), 8(3), 227-248.

Balatti, J., Haase, M., Henderson, L., \& Knight, C. (2010). Developing teacher professional identity through online learning: A social capital perspective.

Beatriz, P., Deborah, N., \& Hunter, M. (2008). Improving School Leadership, Volume 1 Policy and Practice: Policy and Practice (Vol. 1): OECD publishing.

Beltman, S., Mansfield, C., \& Price, A. (2011). Thriving not just surviving: A review of research on teacher resilience. Educational Research Review, 6(3), 185-207.

Bobek, B. L. (2002). Teacher resiliency: A key to career longevity. The Clearing House, 75(4), 202-205.

Brunetti, G. J. (2006). Resilience under fire: Perspectives on the work of experienced, inner city high school teachers in the United States. Teaching and teacher education, 22(7), 812-825.

Castro, A. J., Kelly, J., \& Shih, M. (2010). Resilience strategies for new teachers in high-needs areas. Teaching and teacher education, 26(3), 622629.

Chua, Y. P. (2013). Mastering research statistics: McGraw-Hill Education. 
Doney, P. A. (2012). Fostering Resilience: A Necessary Skill for Teacher Retention. J Sci Teacher Education, 24, 645-664.

Fisher, M. H. (2011). Factors influencing stress, burnout, and retention of secondary teachers. Current issues in education, 14(1).

Friborg, O., Hjemdal, O., Rosenvinge, J. H., \& Martinussen, M. (2003). A new rating scale for adult resilience: what are the central protective resources behind healthy adjustment? International journal of methods in psychiatric research, 12(2), 65-76.

Greenfield, B. (2015). How can teacher resilience be protected and promoted? Educational \& Child Psychology, 32 (4), 52-68.

$\mathrm{Gu}$, Q. (2014). The role of relational resilience in teachers' career-long commitment and effectiveness. Teachers and Teaching, 20(5), 502-529.

Gu, Q., \& Day, C. (2007). Teachers resilience: A necessary condition for effectiveness. Teaching and teacher education, 23(8), 1302-1316.

Gu, Q., \& Day, C. (2013). Challenges to teacher resilience: Conditions count. British Educational Research Journal, 39(1), 22-44.

Henderson, N., \& Milstein, M. M. (2003). Resiliency in schools: Making it happen for students and educators: Corwin Press.

Hjemdal, O., Friborg, O., Stiles, T. C., Martinussen, M., \& Rosenvinge, J. H. (2006). A new scale for adolescent resilience: Grasping the central protective resources behind healthy development. Measurement and evaluation in Counseling and Development, 39(2), 84.

Hong, J. Y. (2012). Why do some beginning teachers leave the school, and others stay? Understanding teacher resilience through psychological lenses. Teachers and Teaching, 18(4), 417-440.

Howard, S., \& Johnson, B. (2004). Resilient teachers: Resisting stress and burnout. Social Psychology of Education, 7(4), 399-420.

Kiswarday, V. (2012). EMPOWERING RESILIENCE WITHIN THE SCHOOL CONTEXT. Methodological Horizons, 7(14).

Knight, C., Balatti, J., Haase, M., \& Henderson, L. (2010). Preservice teacher stressors and their reactions to those stressors: Resilient responses.

Malaysia Chinese News. (30 Jun 2015). Education Department: Many teachers retired this year, three reasons contributed to teacher shortage in SJKC. Retrieved from http://www.malaysianchinesenews.com/2015/ 07/education-department-many-teachersretired-this-year-three-reasons-contributed-toteacher-shortage-in-sjkc/
Mansfield, C. F., Beltman, S., Broadley, T., \& Weatherby-Fell, N. (2016). Building resilience in teacher education: An evidenced informed framework. Teaching and teacher education, $54,77-87$.

Mansfield, C. F., Beltman, S., Price, A., \& McConney, A. (2012). "Don't sweat the small stuff:" Understanding teacher resilience at the chalkface. Teaching and teacher education, 28(3), 357-367.

Noltemeyer, A. L., \& Bush, K. R. (2013). Adversity and resilience: A synthesis of international research. School Psychology International, 34(5), 474487.

Papinczak, T. (2012). Perceptions of job satisfaction relating to affective organisation commitment. Medical education, 46(10), 953-962.

Pavin Ivanec, T., Miljević-Riđički, R., \& Bouillet, D. (2014). Kindergarten Teachers' Resilience and Its Relation to the Parental Behaviour of Their Mothers and Fathers. Hrvatski časopis za odgoj i obrazovanje, 16(Sp. Ed. 2), 109-124.

Razak, A. Z. A. (2013). Learning about teachers' resilience: perceptions, challenges and strategies of policy implementation in two secondary schools in Malaysia: a thesis presented in partial fulfilment of the requirements for the degree of Doctor of Philosophy in Education at Massey University, Palmerston North, Manawatu, New Zealand. Massey University.

Tait, M. (2008). Resilience as a contributor to novice teacher success, commitment, and retention. Teacher Education Quarterly, 35(4), 57-75.

Tatum, R. D. (2007). Study of the relationship of organizational protective processes and teacher resilience.

Tedeschi, R. G., \& Kilmer, R. P. (2005). Assessing Strengths, Resilience, and Growth to Guide Clinical Interventions. Professional Psychology: Research and Practice, 36(3), 230.

Van Breda, A. D. (2000). Prevention of violence towards women and children: A research report (MPI/R/104/12/1/4, dd May 2000). Pretoria, South Africa: South African Military Health Service, Military Psychological Institute, Social Work Research \& Development.

Werner, E. E. (1995). Resilience in development. Current directions in psychological science, 4(3), 81-85. 